\title{
9. Stumbling towards nation-building: impediments to progress
}

\author{
Anthony F. Shepherd
}

\begin{abstract}
On the fiftieth anniversary of the Snowy in 1999, I called for unwavering political support for major infrastructure projects. Support such as was enjoyed by the Snowy project and was essential for its success. Some eight years on we see signs of cautious political support for big projects. Our economic infrastructure still suffers from major gaps particularly in transport (public and private), water, power and ports. We are suffering also from a technical skills shortage. Political support is emerging but is cautious because of the plethora of noisy single-issue groups encouraged by a media greedy for the 20 second grab. Furthermore, defects in our Constitution are exacerbating the problem as Federal and State Governments grapple with problems best dealt with on a national basis.
\end{abstract}

\section{Introduction}

On the fiftieth anniversary of the Snowy in 1999, at a forum not too far from here, I called for unwavering political support for desperately needed major infrastructure projects. I said at that time:

In the last 50 years, it is difficult to think of a major development which has successfully harnessed not just the support of the Australian people but an overwhelming sense of their pride and goodwill ... Development has become an unpopular word; a necessary, if somewhat unfortunate incident of everyday life. A bit boring, a bit inconvenient and definitely bad if it happens anywhere near where somebody lives. (Shepherd 1999)

I went on to observe:

I do not accept that the fact that the tightening of the public purse with respect to major infrastructure projects is the only reason for stalled developments. The private sector is now sufficiently mature to accept responsibility for funding also. With a range of boo [Build, Own and Operate] and boot [Build, Own, Operate and Transfer] projects it has demonstrated its capacity to facilitate and promote the timely provision of high quality public infrastructure.

The Snowy was conceived in the heady excitement for Australia's prospects following WWII. Today, the gung-ho enthusiasm that saw the planning wrapped up in 3 years, public goodwill extend to all the 
workers, and record breaking feats of engineering daring and excellence has largely gone. Today's community is highly informed, highly urbane and generally, anti development.

Political leaders are reluctant to risk popularity through championing projects which may not have overwhelming public enthusiasm. I suggest that such leadership is now critical to pursuing the development of major infrastructure projects. (Shepherd 1999)

What have we done in the eight or so years since then? Have we indeed lost the pioneering nation-building spirit? I am afraid that the score sheet is not all that impressive, especially given the unprecedented prosperity we have enjoyed in this period. We have made some progress but, as a nation, we still face considerable challenges.

Of course, we have the technical capability to undertake major infrastructure projects, as evidenced by projects such as the Lane Cove Tunnel, the Alice to Darwin Railway, Sydney's Cross City Tunnel, Melbourne City Link and the Sydney Airport Railway Link. Some of these projects have been a great success and will continue to make a significant economic contribution for the foreseeable future.

However, if we do a stock take we find that we rank twentieth out of 25 OECD countries for investment in public infrastructure as a percentage of GDP. In a practical sense we find:

1. The queues of ships waiting to load at Newcastle and most of our other coal loading ports are unacceptably long and demurrage cost exporters some $\$ 400 \mathrm{~m}$ in Newcastle alone last year;

2. Public transport is not keeping pace with development as our major cities continue to sprawl and under investment also makes public transport even less attractive when one can buy a brand new air conditioned car for $\$ 15,000$;

3. We still do not have a divided highway linking Melbourne, Sydney and Brisbane, and if we take a lane out on the Sydney Harbour Crossing or the Monash Freeway at peak then Sydney and Melbourne are gridlocked for hours;

4. The rail freight system between Melbourne, Sydney and Brisbane has not improved in 50 years and is still too slow, expensive and unreliable to compete with road transport. Rail has $11-19 \%$ of market share in land freight north and south, whereas investment on the East-West rail link has taken rail freight to over $80 \%$ of market share and shows what can be achieved; 
5. Water supply to major cities and regions in most States is so stressed by the drought that severe water restrictions are now a fact of life and we have no national plan for urban or rural water security;

6. Most of our sewerage still goes into the seas and rivers with limited treatment and there is very limited recycling of sewerage;

7. Broadband access and speeds are amongst the slowest in the OECD where we rank seventeenth out of 30 in terms of broadband penetration;

8. Our public hospitals are reportedly in bad shape and waiting lists continue to grow;

9. Our public education system - once our pride and joy - continues to slip in world terms. As a result, parents are making huge sacrifices to put their children in the private education system;

10. The country, which was once a pioneer in skills training and apprenticeships, now cannot attract enough people with appropriate skills to service the resources boom. We can attract bright students into medicine and law but not many into engineering and the sciences; and

11. We do not have an integrated national plan for power, water or transport nor do we have a truly national market in any of them.

Why is it so? My view, based on 17 early years in the federal public service and followed by 28 years in the private sector, is that it is due to a combination of circumstances.

When I came to Canberra in the late 1960s, the Snowy Project was going strong and the Government and the top federal public servants were focussed almost entirely on national development. Whether that be by direct investment, or by immigration, export policies, education, health or by facilitation. It was an accepted non-debatable truth. We were a young, resourceful country, brash at times, but we were going places. Development was a way of life. The Department I worked for was building and operating NASA tracking stations for the Apollo and other space programs and launching rockets at Woomera. We were also building Mirage fighters. It was all 'go, go, go'!

The same focus applied in each of the States irrespective of their political colour. National development was essential and it was accepted that we could not leave ourselves as vulnerable and defenceless as we were when the Second World War hit Australia like a tsunami.

If we were fortunate enough to travel overseas in the 1950s and 1960s we saw a UK and Europe still struggling to recover from the War and an Asia, both north and south, with a far lower standard of living. Only the United States was booming and investing heavily in its national and industrial infrastructure. The United States was the country we emulated. 
The momentum continued in the 1970s but started to slow coming into the eighties. Other parts of the world not only caught up, but began to surpass us. Western Europe made a remarkable recovery from the War. Asia - particularly countries like Japan -started to really fire. Perhaps we had not so much 'slowed', but rather the competition has lifted.

But the momentum did slow and the current gaps in our economic and social infrastructure and our skills shortages in engineering and science are undeniable. The fact that we are not close to being the number one country in the world on most social and economic indicators is a further sign of our relative decline.

There was no single factor influencing this decline so I will deal with them in no particular order and highlight those I see as interrelated.

The growth of single issue groups with their inevitable opposition to any proposed major development has weakened the political will. The growth and acceptance of these groups is due to a combination of: increasing cynicism about the political process; vastly improved and simplified methods of communication; more sophisticated activism; significant increases in personal wealth; a new libertarian spirit; genuine concern about the environment; and, of course, NIMBYism (Not-In-My-Back-Yard). Furthermore, these groups have been encouraged and fed by a media which can often be disappointingly superficial and sensationalist.

Every major project I have worked on whether it be the Sydney Harbour Tunnel, Melbourne City Link, Eastlink in Eastern Melbourne, the redevelopment of Walsh Bay or even the construction of the ANZAC warships has been criticised by one element of the media at some stage of its development. Negative lobby groups seem to be given better than a 'fair run' by an Australian media that feeds on confrontation. The quality of analysis by the bulk of the print or electronic media is superficial or non-existent.

Could you imagine Sydney today without its Tunnel? Well, Ted Mack, the venerated former Mayor of North Sydney and local Federal MP could. As did that venerable journal of record, the Sydney Morning Herald, when the project was first launched. If you waded through the media at the time Melbourne City Link was getting off the ground you would think it was the end of civilisation as we knew it.

I do listen to the $\mathrm{ABC}$ from time to time to find out what the 'Dark Side' is thinking. Recently, the new Premier of NSW announced the Government's intention to construct a desalination plant. Now, putting aside whether this is a good solution, how did the $\mathrm{ABC}$ deal with this issue? The $\mathrm{ABC}^{\prime}$ s main concern was the potential for disruption in a few streets where a new pipeline would be buried: disruption, which, at worst, would last four weeks. There was no analysis 
of whether this is a good way to drought proof Sydney or any assessment of the Government's published motives and logic.

Under this skewed perspective, the automatic assumption is that the Government is a bunch of fools or knaves. Look at the treatment given to so-called 'development' politicians such as Jeff Kennett, Laurie Brereton, Carl Scully and Nick Greiner. No wonder politicians are nervous about big projects.

A second and related factor leading to a downturn in investment in infrastructure is a combination of political correctness and a planning process in most jurisdictions that appear designed to exhaust any Minister, government department, council or developer.

We still have one of the world's great democracies but we also have a lot of government: three levels all wanting to be involved and to justify their existence. I say, 'For heaven's sake, we elect a Government, let them govern. If you don't like their decisions throw them out at the next election'. Now, even minor decisions must have a major public enquiry going on for months at great taxpayer expense so that every special interest group can have their say. Why bother? They are still going to complain vociferously if the project goes ahead in whatever form.

Don't get me wrong, I'm in favour of community consultation, but it is a matter of degree. If the Government based on all the evidence makes a decision that is in the best interests of the whole community, then let's get on with it.

The third factor has been the anti-debt philosophy developed - quite correctly, in my view - by the Commonwealth and the States in the late 1980s. Although frequently derided as a symptom of 'economic rationalism', this was, at that time, a rational response to some States effectively borrowing to meet recurrent operating expenditure - borrowing to buy your groceries as they say. Fortunately, the Commonwealth and the States, aided by the rating agencies, shut down this binge and governments thereafter went for budget surpluses.

However, the States and the Commonwealth are now pillars of financial rectitude and it is time again to look at Government borrowing to invest in our infrastructure, particularly in those areas which are not attractive to the private sector. These are generally where the private sector does not or cannot take a long enough view. The Sydney Harbour Bridge was vastly overbuilt for the foreseeable requirement at the time. Thank heavens we had visionaries such as Bradfield then. Who is the new Bradfield?

This brings me to another factor. Although I am a fervent supporter and promoter of outsourcing and privatisation, we have taken out of our public service a lot of its talent and we have reduced the breeding grounds necessary to grow and develop the public service. If we are to have leadership and vision from the public sector then we must have a talented and motivated Public Service which 
can initiate, plan, prioritise and supervise the provision of our national infrastructure.

The final factor is an outmoded Constitution. Although the Constitution served us reasonably well for the first 50 or so years of Federation (with a bit of manipulation, and astonishingly progressive interpretation by various High Courts) its drafters did not recognise the need for an integrated national approach to economic and social infrastructure. For example, the Commonwealth is awash with cash from income and company tax. Some of the States are battling financially, particularly with a downturn in revenue from stamp duty. Unfortunately, gambling revenue has been seen as an offset but that is another story.

The Federal AusLink initiative, while far from perfect, has been one of the few exceptions where the Commonwealth and the States have endeavoured to work co-operatively to develop and fund some national priorities in transport. It is not perfect but it is a good start and an example of where the future should lie.

The infrastructure sector is very pleased that the new Rudd Labor Government is onto this issue. The Commonwealth intends to conduct a 'national infrastructure audit' to identify the gaps and establish priorities. It has established a statutory body -Infrastructure Australia - to develop and implement plans for national infrastructure and a special fund - Building Australia - to back it. For the first time, Australia has a dedicated national Infrastructure Minister. These are welcome breakthroughs and should help to depoliticise decision-making. The challenge is not to replicate existing federal and state bureaucracy and not to slow down the process.

Roads, rail, power, water, ports, airports, communications, health and education are all national issues. We are a single nation. We must have an organised and integrated approach. The Commonwealth cannot do it alone as it does not have the bureaucratic infrastructure nor the skills. Subject to my earlier comments about strengthening the public service, the States have a lot more of the skills and experience required to deliver infrastructure. Therefore the Commonwealth and the States must work together. It sounds simple, but it has taken 107 years to get there.

Governments should concentrate on what they do well: that is initiate, plan, prioritise and regulate. The private sector should do what it does best, which is deliver and operate. I could go on forever about the relative efficiencies of government and the private sector, but a simple quotation from that great American philosopher, Will Rogers says it all:

If you want to eliminate traffic congestion then get the private sector to build all the roads and the Government to build all the cars. 
The private sector has the capital, expertise and the will to make an increasingly significant contribution to our nation's economic and social infrastructure. What we need is the market and the political will and, importantly, leadership.

Of course, the development spirit is not totally dead. It lives on in our resources companies that quietly get on with the job in remote parts of the country where they have become virtual governments, effectively and efficiently providing most of the economic and social infrastructure; it lives on in the PPP market where the private sector takes on massive risks and invests huge sums of capital; and it lives on in various premiers, ministers, mayors and public servants who, despite the risks and the counter pressures, assiduously move major projects forward.

\section{References}

Shepherd, A.F. 1999. 'The Spirit of the Snowy - Fifty Years On', Australian Academy of Technological Sciences and Engineering, AATSE Symposium, November 1999, accessed 26 February 2008 at http://www.atse.org.au/index.php?sectionid $=296$ 